\title{
RETINAL HAEMANGIOBLASTOMA*
}

BY

\author{
ACHILLES TAKTIKOS \\ Department of Pathology, Institute of Ophthalmology, University of London
}

ANGIOMATOUs tumours of the retina have been recognized and reported in the literature for many years. Although the first case was recorded by Panas and Remy (1879), and several others followed this publication, retinal angiomatosis was established as a clinical entity, presenting typically in infancy or early childhood, by von Hippel (1904) and was associated with angiomatosis of the central nervous system by Lindau (1927). There is not infrequently a hereditary and familial disposition.

Retinal angiomatosis is an uncommon condition. Usher (1935) collected 119 cases from the literature, and Cordes and Hogan (1940) reviewed 135 recorded cases, but the incidence is thought to be higher than suggested by these figures (Reese, 1951). Angiomata of the retina have also been observed in premature infants (von Hippel, 1934; Ashton, 1961).

A case of angiomatous tumour of the retina, recently examined in the Pathology Department at the Institute of Ophthalmology, is here reported, not only because of its rarity but also because the growth showed an interesting pathological feature only occasionally seen in angiomata, namely a tendency to form pseudoxanthomatous cells within the tumour. This peculiarity was well described in a case reported by Berger and Vallée (1931), who applied the name "angio-reticulo-xanthoma"; it has since been recognized, however, that foam cells are a feature of a particular type of cystic angioma occurring primarily in the retina, cerebellum (Anderson, 1961), and spinal cord or its membranes (Rasmussen, Kernohan, and Adson, 1940). To this tumour the term "haemangioblastoma" is now generally applied.

\section{Case Report}

A 3-month-old female infant was taken to the hospital because her parents had noticed something unusual about her right eye.

Examination (by Mr. V. A. F. Martin of Belfast).-A greyish mass was seen in the vitreous space. The retina appeared totally detached. The left eye was normal and no other abnormality was detected. There was no relevant family history.

As retinoblastoma could not be excluded, the eye was enucleated and sent for histological examination.

Macroscopical Examination.-A lobulated tumour was situated at the periphery, apparently arising from the posterior aspect of the completely-detached retina. It consisted of large bloodcontaining cysts and a deeply-staining, irregular, cellular mass. There was an abundant subretinal exudate containing a small haemorrhage (Fig. 1, opposite).

* Received for publication January 31, 1962. 


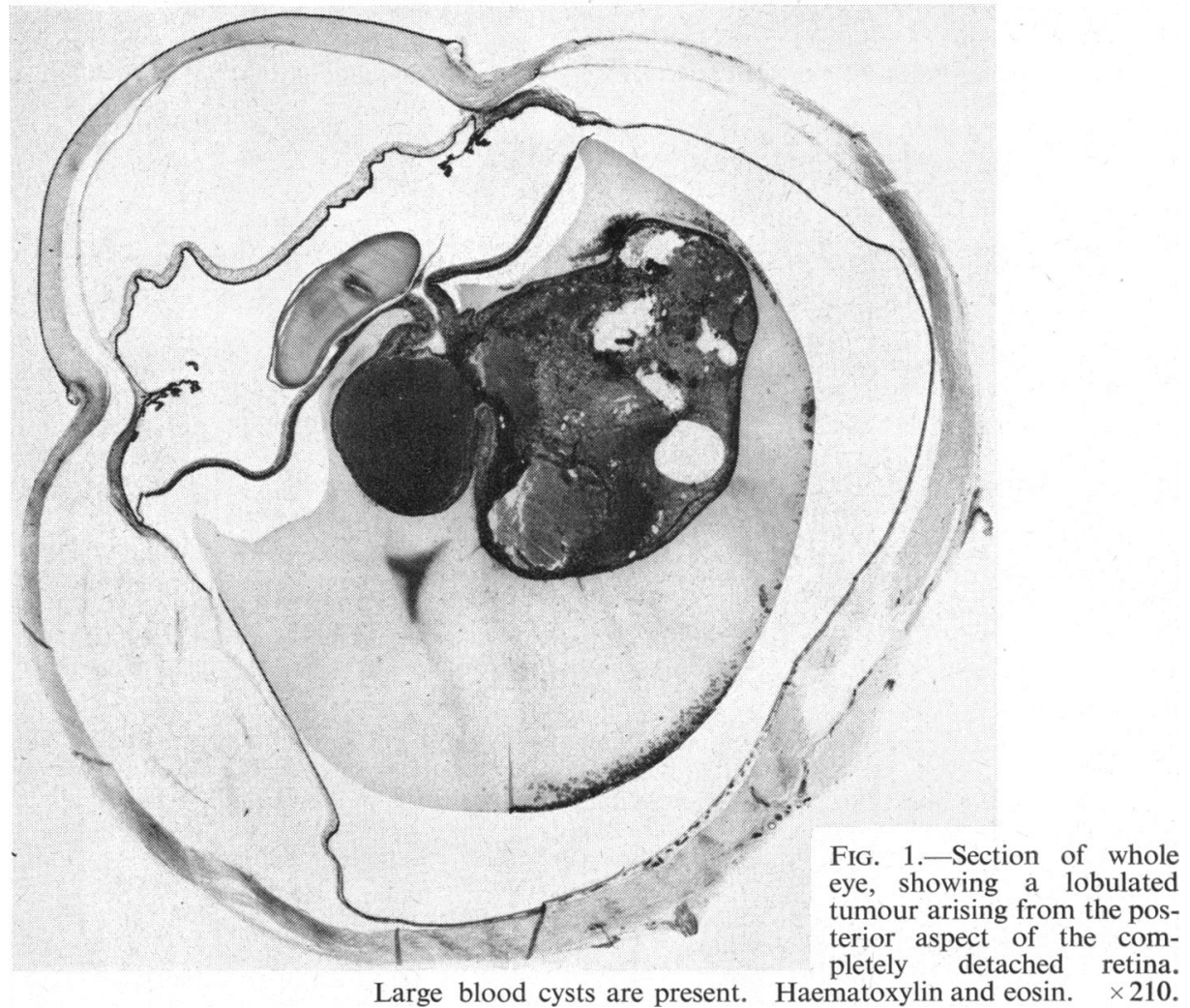

Microscopical Examination.-The main mass of the growth consisted of endothelial or angioblastic cells, closely packed together, but occasionally forming minute capillaries, giving the histological appearance of a haemangioendothelioma or haemangioblastoma (Figs 2 and 3).

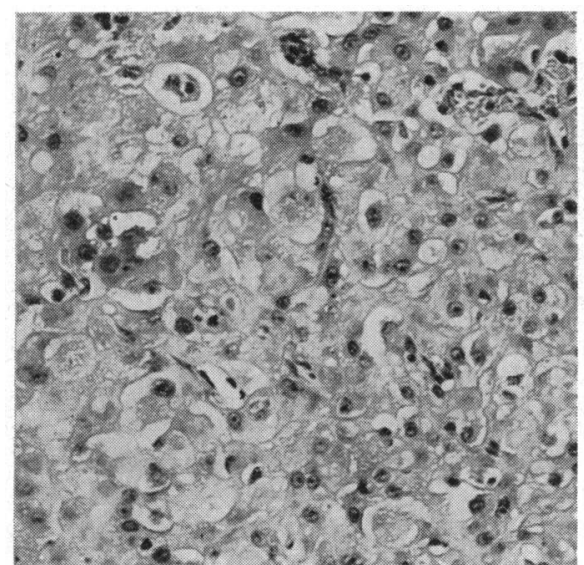

Fig. 2.-The tumour mainly consists of a solid mass of closely packed endothelial cells. Haematoxylin and eosin. $\times 210$.

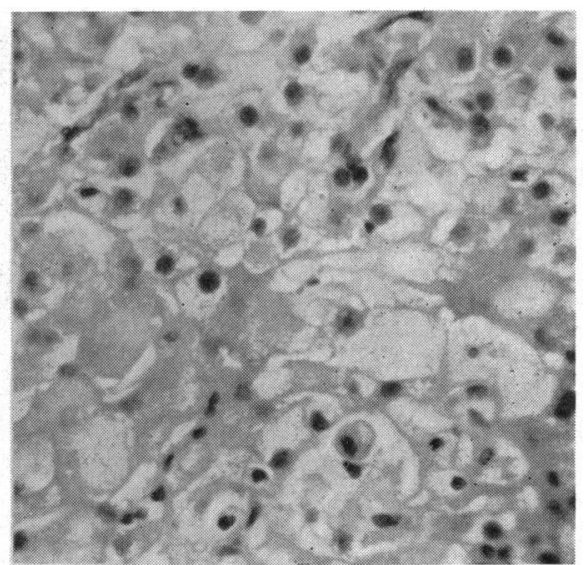

FIG. 3.-Fat-containing endothelial cells resembling Gaucher-cells were present in some areas (See also Fig. 6). Haematoxylin and eosin. $\times 330$. 
A marked reactive gliosis was present in the retina itself (Fig. 4), which also showed cystic degeneration. Large blood-cysts were present which derived from haemorrhages into the tumour tissue and, as was to be expected, the entrapped blood gave rise to haemorrhagic siderosis in the surrounding tissues.

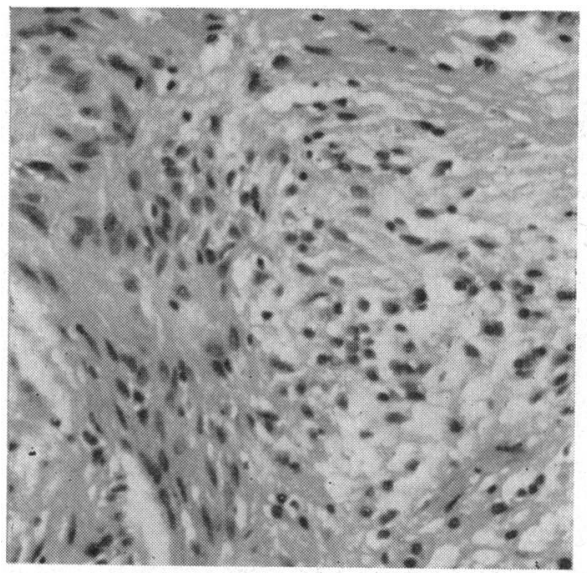

FIG. 4.- Reactive gliosis in the retinal tissue near the tumour. Haematoxylin and eosin. $\quad \times 210$.

Perls's stain showed numerous iron-containing macrophages in the neighbourhood of the haemorrhages (Fig. 5). A certain amount of reticulin could be demonstrated (Wilder's stain) coursing throughout the tumour, but this was less definite in its distribution than usually seen.

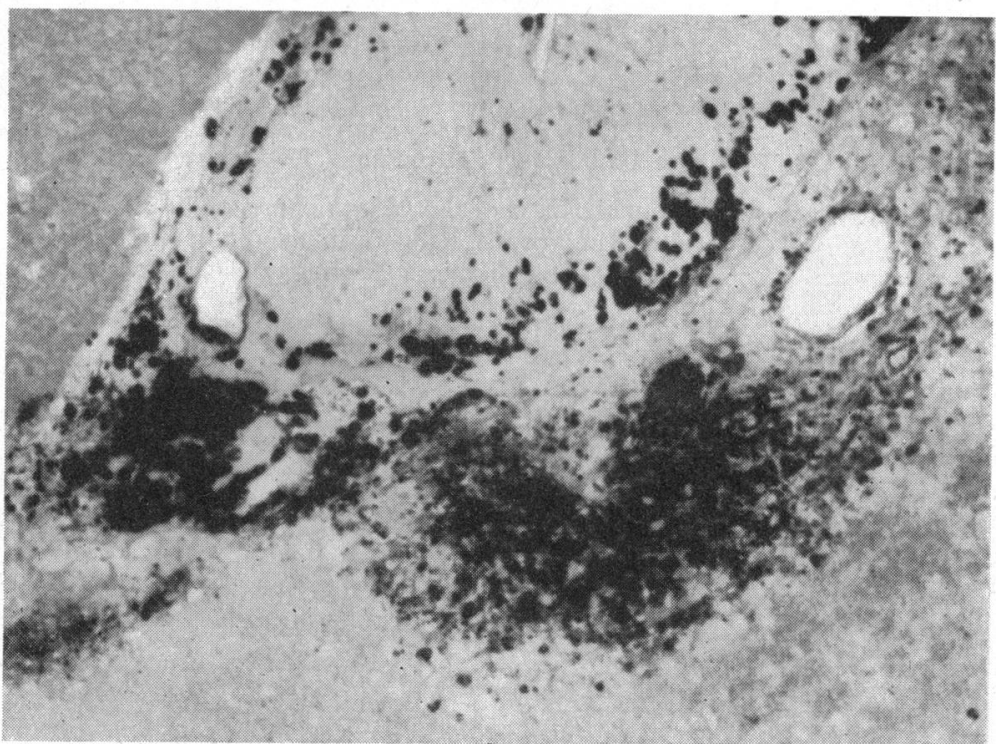

Fig. 5.-Perls's stain shows haemorrhagic siderosis adjacent to the blood cysts.

Haematoxylin and eosin. $\times 110$.

Many of the tumour cells contained fat, as demonstrated in frozen sections stained with Oil red $O$ or Sudan III (Fig. 6, opposite). Some were greatly enlarged to form foam cells resembling Gaucher cells-the so-called "pseudoxanthomatous cells". In polarized light the lipoid granules within the cells were found to be birefringent. Histologically the tumour appeared to be benign. 


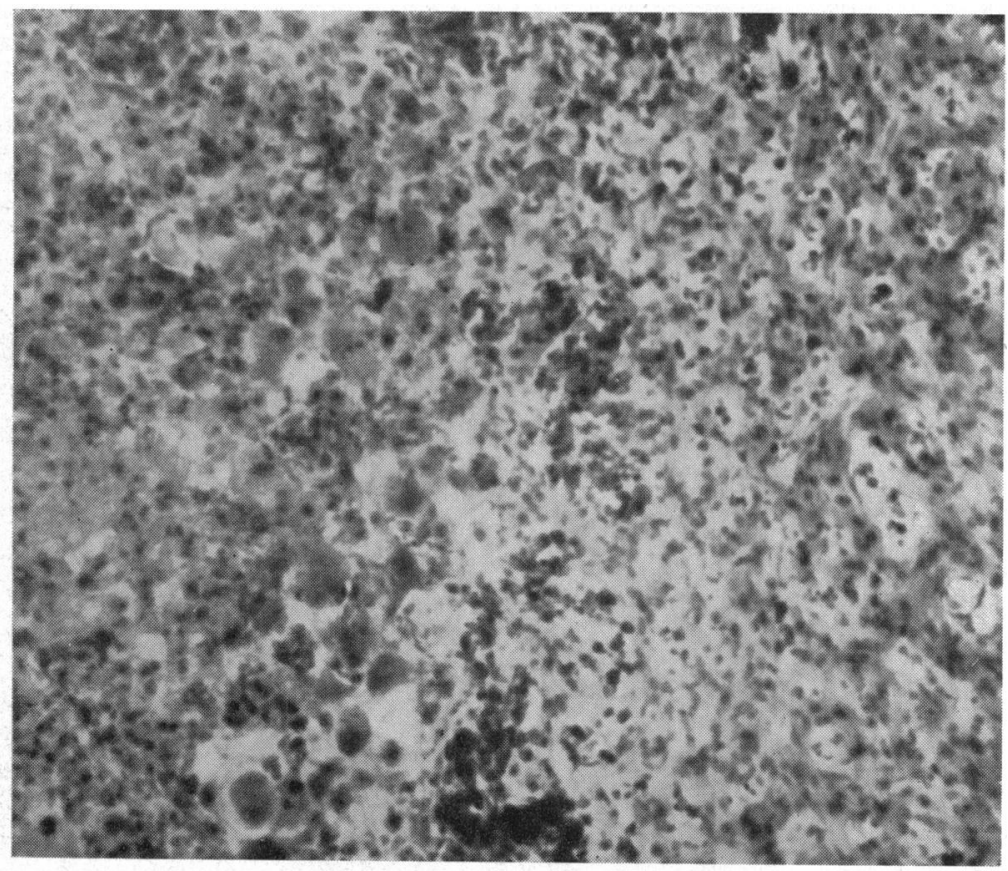

FIG. 6.-Frozen section stained for fat shows numerous fat-laden endothelial cells as seen on the left. Oil red $O . \times 172$.

Follow-up.-In view of the xanthomatous appearances of the tumour a blood cholesterol was carried out and found to be within the normal range. A general medical examination revealed no extra-ocular abnormality. No complication has occurred and the child is well one year after the excision, suggesting that the retinal haemangioblastoma was probably an isolated lesion.

\section{Comment}

This case is a typical example of haemangioblastoma of the retina, showing all the features previously described as "angio-reticulo-xanthoma" (Berger and Vallée, 1931) or as "angioreticuloma" (Roussy and Oberling, 1930), and is to be regarded as a variety of angiomatosis retinae. The glial tissue, once thought to be the primary pathological component (Meller, 1913), or at least as important as the endothelial cells (hence "angiogliomatosis"), is now known to be merely a reactive gliosis; a view supported by the histology of this case. The cystic nature of the tumour is similar to that seen in the cerebellar haemangioblastomata, which may be associated, while the siderosis and pseudoxanthomatous changes are secondary features. The nature of the pseudoxanthomatous cells is uncertain, but they are probably endothelial cells which have phagocytosed fat that accumulated locally from stasis or from an impaired capacity to metabolize it. Reticulin proliferation is also a characteristic feature and appears to be laid down by the angioblasts 
themselves, so that a delicate reticulin framework outlines individual cells, groups of cells, or the lumina of developing capillaries. The peripheral location of the growth was typical.

These tumours are generally classified by pathologists as developmental vascular hamartomata (Willis, 1960) and not as true neoplasms, although Reese (1951) is not in agreement. Berger and Vallée (1931) believed their case to be malignant, but the one here described is clearly benign as would be expected in a hamartoma. In any event, a retinal haemangioblastoma is likely to destroy the eye through repeated haemorrhages, organizing fibrosis, and retinal detachment, terminating in atrophia bulbi-as in the present case. Metastases from a retinal haemangioblastoma have not been reported and it would seem doubtful whether angiosarcoma ever occurs in retinal tissue.

\section{Summary}

A case of haemangioblastoma of the retina is reported, and the pathology and nature of the tumour are briefly discussed.

My thanks are due to Prof. Norman Ashton for his assistance in the preparation of this report, and to Mr. V. A. F. Martin for permission to publish the case. I am also indebted to Mr. G. Knight and Mr. A. McNeil for technical assistance and to Miss E. FitzGerald for secretarial help.

\section{REFERENCES}

Anderson, W. A. D. (1961). “Pathology", p. 1332. Mosby, St. Louis.

AsHTON, N. (1961). Personal communication.

Berger, L., and Vallée, A. (1931). Ann. Anat. path., 8, 313.

Cordes, F. C., and HogAN, M. J. (1940). Arch. Ophthal. (Chicago), 23, 253.

HIPPEL, E. von (1904). v. Graefes Arch. Ophthal., 59, 83. (1934). Ibid., 132, 256.

LindaU, A. (1927). Acta ophthal. (Kbh.), 4, 193.

Meller, J. (1913). v. Graefes Arch. Ophthal., 85, 255.

Panas, F., and Remy, A. (1879). "Anatomie pathologique de l'oeil", p. 88. Delahaye, Paris.

Rasmussen, T. B., Kernohan, J. W., and Adson, A. W. (1940). Ann. Surg., 111, 513.

ReESE, A. (1951). "Tumors of the Eye", p. 364. Hoeber, New York.

Roussy, G., and Oberling, C. (1930). Presse méd., 38, 179.

UsHeR, C. H. (1935). Trans. ophthal. Soc. U.K., 55, 183.

WILlis, R. A. (1960). "Pathology of Tumours", 3 ed., p. 712. Butterworths, London. 